\title{
Analysis of antidiarrhoeic effect of plants used in popular medicine*
}

\author{
Cybele E. Almeida, Margô G.O. Karnikowski, Rejane Foleto and Bernardo Baldisserotto \\ Departamento de Fisiologia, Universidade Federal de Santa Maria - Santa Maria, RS - Brasil
}

\begin{abstract}
People customarily use the extracts of plants known to have antidiarrhoeal effects without any scientific base to explain the action of the extract. For this reason, an investigation was undertaken with a view to determining the efficacy of the effects of the brute aqueous extract (BAE) of the leaves of Psidium guajava (guava), Stachytarpheta cayenensis (bastard vervain), Polygonum punctatum (water. smartweed), Eugenia unilfora (Brazil or Surinam cherry) and Aster squamalus (ze-da-silva) on the intestinal transport of water in rats and on the gastrointestinal propulsion in mice. With the exception of the BAE of S. cayenensis, all other BAE's have increased the absorption of water In one or more intestinal portion in relation to the control group. All tested BAE, except that of $P$. punctatum, reduced the gastrointestinal propulsion in relation to that of the control group. The results indicate that the BAE of the leaves of $P$. guajava, $S$. cayenensis, $P$. punctatum, $E$. uniflora and $A$. squamatus have a potential antidiarrhoeic effect to be confirmed by additional investigatlons in animals infected with enteropathogenic agents.
\end{abstract}

Diarrhea, therapy. Plant extracts, pharmacology. Plants, medicinal.

\section{Introduction}

In the Third World, diarrhoeal diseases are responsible for the deaths of millions of people each year ${ }^{22}$ and it is, thus, a serious public health problem. Most persons who suffer from this problem are socially underprivileged individuals, and consequently, almost without access to alopathic medicine. For this reason, an investigation was made with a view to determining the efficacy of those plants commonly used in Southern Brazil for medical diarrhoeic care: Psidium guajava L. var. pommiferum (guava/goiabeira), Stachytarpheta cayenensis (L.C. Rich) Vahl. (bastard vervain/gervão), Polygonum punctatum Elliot. (water smartweed/polígono or pimenta d’água), Eugenia uniflora L. (Brazil or Surinam cherry/pitangueira) and Aster squamatus (Spreng.) Hieron (zé-da-silva). The leaves, roots and flowers of $P$. guajava are customarily used in tropi- cal and subtropical regions $s^{4,16,17,18,28}$. The roots and leaves of $S$. cayenensis are utilized in Northern Brazil. A plant of the same genus, Stachytarpheta jamaicensis, found in tropical and subtropical regions is also used to treat dysentery and intestinal worms ${ }^{24,30}$. The entire $P$. punctatum plant is used to treat dysentery in Central and South Americas ${ }^{10.28}$. The leaves of $E$. uniflora are used in tropical and subtropical regions ${ }^{1,30}$. The aerial portion of A. squamatus is used in Southern Brazil ${ }^{* *}$.

\section{Materlal and Method}

The plants were collected between September 1991 and January 1992, after which the leaves were dried at room temperature and the BAE prepared by an infusion of $16.67 \mathrm{~g}$ of dried leaves in one litre of Tyrode solution or water (similar to the infusion used by people). Adult male Wistar rats

"Presented in the "III Somada de Pesquisa of the Universidade Federal de Santa Maria, Santa Maria (September 93) and "XVIII Congreso Latihoamericano de Ciencias Fisiologicas, Montevideo" (April 94).

"A.M.V, Lopes et al "Plantas usadas na medicina popular em Santa Maria, Rio Grande do Sul, Brasil" (unpublished).

Reprints: Cybele E. Almeida - Departamento de Fisiologia, Universidade de Santa Maria - 97119-900-Santa Maria, RS - Brasil Fax (05S) 226.24.23-E.mail - CYBELE@SUPER.UFSM.BR

Received in 1.19.1995. Approved in 10.2.1995. 
(150 - 200g) in fasting ( $24 \mathrm{~h}$ ) were used to investigate the transport of water, and were sacrificed by cerebral concussion. The abdomen was opened, and the intestine separated in the following portions: duodenum, jejunum, ileum and colon. These portions were everted and washed with Tyrode solution. The flow of water was determined as described by Baldisserotto et al. ${ }^{2}$ To verify the "in vitro" effect of the plants the BAE was placed in the infusion, in contact with the intestinal mucosa. The flow of water was expressed as $\mathrm{ml}$ of water transferred from mucosa to serosa (negative values) or serosa to mucosa (positive values) in function of the weight of the tissue (duodenum, jejunum, ileum or colon) in g during $1 \mathrm{~h} \mathrm{(ml/g} \mathrm{tis-}$ sue.h). An adaptation of the method described by Janssen and Jageneau ${ }^{15}$ was used to investigate the gastrointestinal propulsion. Mice $(15-45 \mathrm{~g})$ in fasting ( $24 \mathrm{~h}$ ) were fed a solution of $0.1 \mathrm{ml} \mathrm{BAE}$ per $10 \mathrm{~g}$ live weight, that contained a $10 \%$ charcoal suspension as an indicator of gastrointestinal propulsion, by gastric intubation. The control group received the same treatment, but the BAE was substituted for water. Forty-five minutes later, the mice were sacrificed, the gastrointestinal tract excised, from cardia to anus, and carefully laid out for measurement of the distances travelled by the charcoal. The gastrointestinal propulsion was expressed as fractional values of the distance travelled by the charcoal in relation to the total length of the intestine. These fractional values were used because the total length of the intestines of mice was variable.

All values are expressed as the mean $\pm \mathrm{SE}$, and the t-Student Test was used to verify the statistical significance of the difference between means (control and with BAE).

\section{Results}

The flow of water was from serosa to mucosa (secretion) in the control group. The BAE of $P$. guajava increased the absorption of water in the colon, but there was no alteration of the flow of water in the other portions. The BAE of $S$. cayenensis did not change the transport of water in relation to the control group in the portions analysed. The BAE of E. uniflora increased the absorption of water in all portions, except the jejunum. The absorption of water increased in all portions when the $\mathrm{BAE}$ of $A$. squamatus was used. The BAE of $P$. punctatum increased the absorption of water in the ileum, but there was no change in the flow of water in other portions (Figure 1A and B, Table 1).

All BAE tested, except that of $P$. punctatum, reduced the gastrointestinal propulsion in relation to that of the control group (Figure 2 and Table 2).

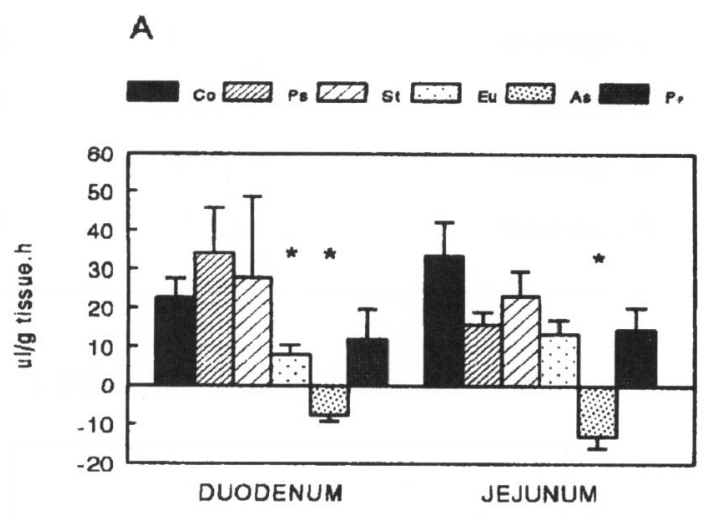

B

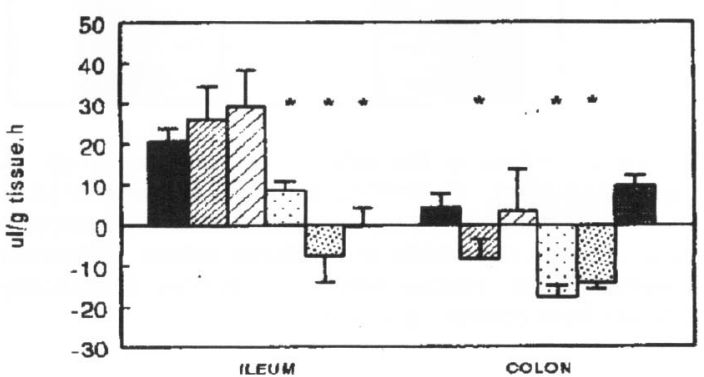

Flgure 1 - Effect of the BAE of $P$. guajava (P.g), $S$. cayenensis (S.C), E. uniflora (E.U), A. squamatus (A.S) and $P$. punctatum (P.p) on the transport of water in the different portions of the intestine of rats.
A - Duodenum and jejunum
B - lleum and colon
statistically different from control ${ }^{*} p<0.05$

\section{Discussion}

The viscosity of the faecal bolus basically depends on the absorption of water and the intensity of the gastrointestinal propulsion. A decrease in the absorption or hypersecretion of water and a higher intestinal motility which decreases the solidity of the faeces was observed in diarrhoea ${ }^{12}$. This change in the flow of water is due to an increase in the secretion of $\mathrm{Cl}$ - or $\mathrm{HCO}_{3-}$, and an inhibition of the absorption of $\mathrm{Na}+$ and $\mathrm{Cl}^{-}$. . To be considered as having an antidiarrhoeic effect, a drug must produce an inverse diarrheal effect, i.e., it must decrease the 
Table 1 - Effect of the BAE of $P$. guajava, S. cayenensis, $E$. unifiora, A. squamatus and $P$. punctatum on the transport of water in the different portions of the intestine of rats. Number of experiments between parenthesis.

\begin{tabular}{|c|c|c|c|c|}
\hline \multirow[b]{2}{*}{ Plant } & \multicolumn{3}{|c|}{ Flow of water (ul/g tissue.h) } & \multirow[b]{2}{*}{ Colon } \\
\hline & Duodenum & Jejunum & lleum & \\
\hline Control & $22.7 \pm 5.0(7)$ & $33.5 \pm 8.6(9)$ & $20.6 \pm 3.2(7)$ & $4.4 \pm 3.4(7)$ \\
\hline P. guajava & $\begin{array}{l}34.2 \pm 11.5 \\
\text { (5) }\end{array}$ & $15.8 \pm 3.3(5)$ & $26.3 \pm 7.9(5)$ & $-8.3 \pm 4.7(6)$ \\
\hline S. cayenensis & $\begin{array}{l}27.9 \pm 20.9 \\
(4)\end{array}$ & $23.3 \pm 6.4(5)$ & $29.1 \pm 9.2(6)$ & $3.5 \pm 10.3(6)$ \\
\hline E. unifiora & $8.1 \pm 2.5(4)$ & $13.5 \pm 3.5(4)$ & $8.5 \pm 2.5(6)$ & $\begin{array}{c}-17.5 \pm 2.6 \\
\text { (5) }\end{array}$ \\
\hline A. squamatus & $\begin{array}{c}-7.76 \pm 1.4 \\
(5) \star\end{array}$ & $\begin{array}{c}-13.1 \pm 3.0 \\
(5) \pm\end{array}$ & $-7.7 \pm 6.3(5)$ & $\begin{array}{c}-14.2 \pm 1.4 \\
(6) *\end{array}$ \\
\hline$P$. punctatum & $\begin{array}{l}12.0 \pm 7.7 \\
(4)\end{array}$ & $14.6 \pm 5.5(4)$ & $-0.2 \pm 4.5(4)$ & $9.7 \pm 2.7(3)$ \\
\hline
\end{tabular}

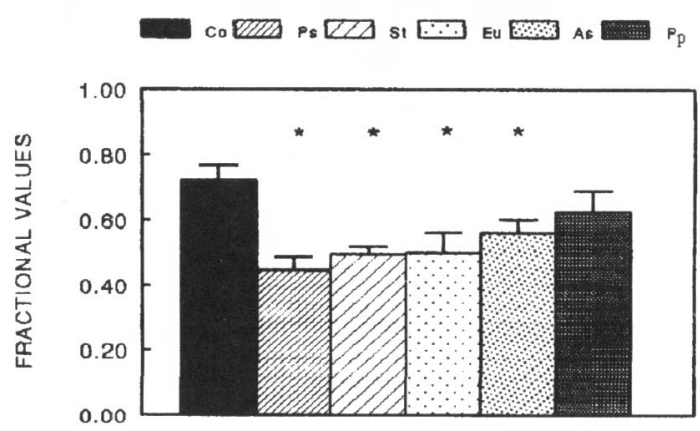

Flgure 2 - Effect of the BAE of P. guajava (P.g), $S$. cayenensis (S.C), E. unifiora (E.U), A. squamatus (A.s) and P. punctatum (P.p) on gastrointestinal propulsion in mice. Results expressed in fractional values (distances travelled by the charcoal/length of intestine). Statistically different from control ${ }^{*} p<0.05$

secretion (or increase the absorption) of water and reduce the intestinal motility.

Field studies of the World Health Organization have demonstrated that the oral rehydration therapy (ORT) is effective in the treatment of all diarrhoeas $^{19}$. However, the availability of ORT, especially in poor Third World countries, is low. By 1989 , the number of countries that used the ORT was 60 . Poorer countries, where the diarrhoeas are the main cause of mortality, may not be able to produce the oral rehydration salts or distribute them ${ }^{18}$. On the other hand, the medicinal plants that could be used to treat diarrhoea (for example, all the plants utilized in this experiment) are frequently of easy access and can be obtained free of charge.

The leaves of the guava, $P$. guajava, have been used as folk remedies in the areas where it grows. In some places the leaves are chewed for the relief of discomfort and pain associated with the gas- troenteritis of diarrhoea, as well as for stopping it. The same effect can be obtained using a decoction of the leaves, bark of the stem or root ${ }^{17}$. In SouthEast Asia, the leaf is given to the giant thorny stick insect, Hepteropteryx dilata or other insects, and the faeces are collected in dry pellet form. These pellets are mixed with hot water to make a pleasantly flavoured wine-coloured drink, which is claimed to be efficacious in the treatment of acute diarrhoeas ${ }^{17}$.

The leaf of this plant contains approximately $10 \% \operatorname{tannin}^{700: 21}$ and also quercetin ${ }^{26}$. Plants that have tannins in their composition can present an anti-diarrhoeic effect, since these substances precipitate the proteins of the enterocytes, reducing the peristaltic movements and the intestinal secretions. The layer formed by the precipitate of proteins on the mucosal surface of the enterocytes also inhibit the development of micro-organisms, thus explaining the antiseptic action of the tannins, which contributes to the treatment of diarrhoe ${ }^{8}$. Quercetin is the most frequent of all flavonoids', and inhibits the release of acetylcholine in the guinea-pig's ileum and the synthesis of prostaglandins $^{29}$. In man, prostaglandins cause

Table 2 - Effect of the BAE of $P$. guajava, $S$. cayenensis $E$. unifiora, $A$. squamatus and $P$. punctatum on gastrointestinal propulsion in mice. Fesults expressed in fractiona values (distances travelled by the charcoal/length of intestine). Number of experiments between parenthesis.

\begin{tabular}{ll}
\hline Plant & Gastrointestinal propulsion (fractional values) \\
\hline Control & $0.72 \pm 0.05(12)$ \\
$P$. guajava & $0.45 \pm 0.04(8) \cdot$ \\
S. cayenensis & $0.50 \pm 0.02(8) *$ \\
E. uniflora & $0.50 \pm 0.06(8) *$ \\
A. squamatus & $0.56 \pm 0.04(17) *$ \\
P. punctatum & $0.63 \pm 0.06(8)$ \\
\hline
\end{tabular}

statistically different from control ${ }^{*} p<0.05$ 
intestinal cramps and diarthoea ${ }^{31}$. Consequently, a drug that decreases the synthesis of prostaglandins could be useful in the treatment of diarrhoea. The extract of leaves of $P$. guajava also inhibits the spontaneous contractions in the ileum of the guinea-pig ${ }^{16,17}$ and the in vitro growth of three enterobacteria (Escherichia coli, Salmonella enteritidis and Shigella flexnerij ${ }^{4,5}$. The antibiotic activity is attributed to two compounds of the extract, guajaverin and psidiolic acid, ${ }^{3,5}$.

The chemical composition of the genus Stachitarpheta has never been investigated. Another species of the genus Stachitarpheta ( $S$. indica) is utilized in the treatment of diarthoea in Eastern Africa ${ }^{32}$. Our results also confirm the possibility of the existence of an antidiarrhoeic substance in $S$. cayenensis, since its BAE reduces the gastrointestinal propulsion. The presence of active substances like tannins were also determined in $E$. uniflora ${ }^{32}$.

Flavonoids were found in the flowers of $A$. squamatus $^{25}$. Another phytochemical study with the leaves, stem and roots of this plant revealed the presence of tannins ${ }^{15}$. A. squamatus was the most efficient among the plants studied, as regards its possible antidiarrhoeic effect, since its $\mathrm{BAE}$ increased the absorption of water in all portions analysed and reduced the intensity of the gastrointestinal propulsion. These results justify the popular use of A. squamatus in the treatment of diarrhoeal diseases in infants in Southern Brazil ${ }^{15}$.

$P$. punctatum has been used in enemas as a treatment for dysentery ${ }^{10}$. Several species of the genus Polygonum, including $P$. punctatum, contain great amounts of tannins $s^{14}$. Quercetin and sesquiterpenoids (with antimicrobian activity) were also isolated from the extract of this

\section{References}

1. ALBUQUERQUE, J.M. Plantas medicinais de uso popular. Brasília, Associação Brasileira de Educação Agrícola Superior/MEC, 1989.

2. BALDISSEROTTO, B.; MIMURA, O.M.; SALOMÃO, L.C. Effect of $\mathrm{pH}$ on ion and water transport in the gut of the freshwater teleost, Synbrancbus marmoratus. Ciênc. Cult. 45:396-8, 1993 .

3. BERDY, J.; ASZALOS, A.; BOSTLAN, M.; MCNITT'T, K.L. Hand book of antibiotic compounds. Boca Raton, CRC Press, 1982.v.8, pt.1: 410 and pt. 2:429.

4. CACERES, A.; CANO, O.; SAMAYOA, B.; AGUILAR,L. Plants used in Guatemala for the treatment of gastrointestinal disorders. species $^{11.34}$. Aqueous and alcoholic extracts of this plant reduced the effect of ocitocin and acetylcholine in the rat's uterus. This reduction was not observed if the extracts were tanninfree $^{23}$ However, Chagas et al ${ }^{6}$ did not find any effect of the aqueous extract of $P$. acre in the same organ.

In the present study, the BAE analysed (except that of $S$. cayenensis) reduced the secretion of some portions of the intestine. It is possible that its effect is due to the presence of tannins in the BAE of $P$. guajava, $E$. uniflora, $A$. squamatus and $P$. punctatum. The reduction of the gastrointestinal propulsion observed with the use of the BAE of $P$. guajava, $E$. uniflora and $A$. squamatus could also be due to the tannins. This effect of the BAE of $P$. guajava is in agreement with the fact that a similar extract of this plant inhibited the spontaneous contractions in the ileum of the guinea-pig ${ }^{17.18}$. Since the chemical composition of $S$. cayenensis is not known, it is not possible to explain its effect on gastrointestinal propulsion.

The results of this study indicate that the plants analysed have a potential antidiarrhoeic effect. However, more studies must be undertaken on infected animals with varying doses of the same extract. Further pharmacological, toxicological and clinical work on these plants is needed before they can be used as an alternative treatment for diarrhoeas.

\section{Acknowledgement}

To Prof. Amelia Moema Lopes of the "Universidade Federal de Santa Maria" for her help in the collection and classification of the plants used in this experiment.

1. Screening of 84 plants against enterobacteria. J.Etbnopbarmacol., 30:55-73, 1990.

5. CACERES, A.; FLETES, L.; AGUILAR, L.; RAMIREZ, O.; FIGUEROA, I.; TARACENA, M.A.; SAMAYOA, B. Plants used in Guatemala for the treatment of gastrointestinal disorders. 3.Confirmation of activity against enterobacteria of 16 plants. $J$. Ethnopharmacol, 38:31-8, 1993.

6. CHAGAS, A.M.; TEIXEIRA, A .H.; DALOSTO, C.; BOLASSE, C.; BORTOLUZZI, M.A.M.; JUCHEM, W.R Efeito protetor de Polygonum acre H.B.K. sobre as hemorragias artificiais em camundongos. Saude, 15:105-16, 1989.

7. CORREA, M.P. Diccionánio das plantas úteis do Brasil e das exóticas cultivadas. Brasília, Ministério da Agricultura/IBDF, 1984. 
8. COSTA, A.F. Fammacognosia, 3th ed. Lisboa, Fundação Calouste Gulbenkian,1975, v.1

9. FIELD, M. \& SEMRAD, C.E. Toxigenic diarrheas, congenital transport. Annu. Ret: Pbysiol. 55:631-55, 1993.

10. FONT-QLER, P. Plantas medicinales. 2th ed. Barcelona, Ed. Labor, 1973.

11. FLKLYAMA, Y.; SATO, T.; ASAKAWA, Y; TAKEMOTO, T, A potent cytotoxic warburganal and related drimane-type sesquiterpenoids from Polygonum bidropiper. Pbytocbemistry, 21:2895-8, 1982.

12. GUYTON, A.C. Tratado de fistologia médica. 7 th ed. Rio de Janeiro, Guanabara Koogan, 1989.

13. HAVSTEEN, B. Flavonoids, a class of natural products of high pharmacological potency. Biocbem. Pharmacol, 32:1141-2, 1983.

14. HEGNAUER, R. Cbemotaxonomie der pflanzen. Stuttgart, Birkhauser, 1962-1973.

15. KARNIKOWSKI, M. G. O.; BALDISSEROTTO, B.; BORTOLLZZI, M.A.M. Screening do extrato aquoso bruto (EAB) de Aster squamatus (Spreng) Hieron, In : Encontro de Ciências Físiologicas do Cone Sul, $1^{\mathrm{D}}$, Santa Maria, 1994. Anais, 1994, p.34.

16. IOZOYA, X; BECERRLL, G; MARTIXEZ, M. Modelo de perfusión intraluminal del ileon del cobayo in vitro en el estudio de las propriedades antidianréicas de la guajaba (Psidium guajava). Ancb. Invest. Méx., 21:155-62, 1990.

17. LUTTERODT, G.D. Inhibition of gastrointestinal release of acetylcholine byquercetin as a possible mode of action of Psidium guajava leaf extracts in the treatment of acute diarrhoeal disease. J. Etbnopharmacol, 25:235. 47,1989 .

18. LETTERODT, G.D. Inhibition of Microlax"induced experimental diarrhoea with narcoticlike extracts of Psidium guajava leaf in rats. J.Ethnopharmacol.37:15l-7, 1992.

19 MARTINEZ, C.A.; BARUA, D.; MERSON, M. H. Control of diarrhoeal diseases. World Health Stat. Q, 41:74-81, 1988.

20. MISRA, K. \& SESHADRI, T.R. Chemical components of the fruits of Psidium guajaua. Pbytocbemistry, 7: 641-5, 1968.

21. OKLDA, T.; YOSHIDA, T.; HATANO, T.; YAZAKI, K.; IKEGAMI, Y.; SHINGU, T. Guavins A, C and $\mathrm{D}$, complex tannins from Psidium guajava. Chem. Pharm. Bull. Tokyo, 35:3-6, 1987.

22. POWELI, D.W. Ion and water transport in the intestine. In: Andreoli, T.E.; Hoffman. J.F.; Faunstial, D.O.; Schultz, S.G. Membrane transport processes in organized systems. New York, Plenum Medical Book Company, 1987. p. $175-212$.
23. RIBEIRO-do-VALLE, R.M.R.; SLMÒES, C.M.O; POLI, A.; NICOLAL, M.; ZANIN, M. Efeito dos extratos de Polygonum acre H.B.K. Fam Polygonaceae (Erva-de-bicho) sobre os efeitos contráteis induzidos pela acetilcolina e ocitocina no útero isolado de rata. Efeito da presença de taninos. In: Reuniào Anual da Federação das Sociedades de Biologia Experimental, 3a Caxambu, 1988. Anais, Caxambu, 1988. p.200.

24. ROBINSON, R. D.; WILLIAMS, L. A. D.; LINDO, J. F,; TERRY, S.I.; MANSINGH. A. Inactivation of strongyloides filariform larvae in vitro by six Jamaican plant extracts and three commercial antihelmintics. West Indian Med. J., 39:213-17, 1990.

25. ROSS, S.A,; SAYED, H. M; EL-SAYYAD, S. M. Phytochemical studies on Aster squamatus L Part II : Sesquiterpene lactones, triterpenes and sterol present in the flowers. Bull. Pbarm. Sci, 7: 389-97, 1984.

26. SESHADRI, T.R.; VASISHTA, K. Polyphenols of the leaves of Psidium guajava - Quercetin, guijaverin, leucocyanidin and amritoside. Pbytocbemistry, 4:989-92, 1965.

27. SIMǑ̃E, C.M.O. Investigaçâo químico-farmacológica de Acbyroline satureoides (Lam.) D.C. Compositae (Marcela). Porto Alegre, 1984. [Tese de Mestrado - LFRGS].

28. SIMOES, C.M.O.; MENTZ, L.A.; SCHENKEL, J.R.; IRGANG, B.E.; STEHMANN, J.R. Plantas da medicina popular no Rio Grande do Sul. Porto Alegre, Editora da Universidade Federal do Rio Grande do Sul, 1986.

29. SWEIS, J.; ROBAK, J.; DABROWSKI, L.; DLNICZ, S.; MICHALSKA, Z.: GRYGIENSKI, R. J. Antiaggregatory effects of flavonoids in vitro and their influence on lipoxygenase and cyclooxygenase in vitro. Pol. J. Pbarnacol. Pharm., 36:455-63, 1984.

30. USHER, G. A dictionary of plants used bv man. London, Oxley Printing Group, 1974.

31. VERMIS, B.; FARKAS,L.; NORGRADI, M. Synthesis of natural diglucosides of quercetin. In: Farkas, L; Gabor, M.; Kallay, F. (Eds)., Topics in flavonoid chemistry and biochemistry. In: Hungarian Bioflavonoid Symposium, 4th, Keszthely, 1973. Proceedings. Amsterdam, Elsevier Scientific Publishing Company, p. 162-70.

32. WATT, J.M. \& BREYER-BRANDWIJK, M.G. The medicinal and poisonous plants of southern and eastem Africa. 2th ed. Edinburgh, E. \& $\mathrm{S}$. Livingstone, 1962.

33. YUSIF, K. S. \& BLINOVA, K. F. Flavonol aglycons of Polygonum bidropiper. kbim. Prir. Soedin., 5: 658-9. [Abstract in: Cbem. Absts., 102: $42886 y, 1985$ ] 


\section{Resumo}

Para combater a diarríia multas vezes as pessoas utilizam extratos de plantas conhecides popularmente como antjdiarrélcas, mesmo sem base cientílica. Em razåo disto, verificou-se o efeito do extrato aquoso bruto (EAB) das folhas da Psidium guajava (goiabeira), Stachytarpheta cayenensis (gerväo), Polygonum punctatum (poligono ou pimenta d'água), Eugenla unif́lora (pitangueira) $\theta$ Aster squamatus (ze-da-silva) no transporte intestinal de água em ratos e na propulsăo gastrointestinal em camundongos. Com excecăo do EAB de $\mathrm{S}$. cayenensis, os demais aumentaram a absorcăo de água em uma ou mals porçoes do intestino em relaça ao gnpo-controle. Todos os EAB testados, com exceçāo do P. punctatum, reduziram o trânsito intestinal em relacáa ao gnupo-controla. Com base nos resultados obtidos conclui-se que os EAB das folhas de P. guayava, S. cayenensls, P. punctatum, E. Lniflora e A. squamatus têm potencial açáto anti-diarréica, a ser confirmada em novas investigaçoes em animais infectados por agentes enteropatogénicos.

Diarréta, terapia. Extratos vegetais, farmacologia. Plantas medicinais. 